This PDF is a selection from an out-of-print volume from the National Bureau of Economic Research

Volume Title: Aging Issues in the United States and Japan

Volume Author/Editor: Seiritsu Ogura, Toshiaki Tachibanaki and David A. Wise, editors

Volume Publisher: University of Chicago Press

Volume ISBN: 0-226-62081-6

Volume URL: http://www.nber.org/books/ogur01-1

Publication Date: January 2001

Chapter Title: The Motivations for Business Retirement Policies

Chapter Author: Richard Woodbury

Chapter URL: http://www.nber.org/chapters/c10293

Chapter pages in book: (p. 307 - 334) 


\title{
The Motivations for Business Retirement Policies
}

\author{
Richard Woodbury
}

\subsection{Introduction}

Most traditional defined benefit pension plans in the United States encourage older workers to retire. For long-service employees, the financial incentive to retire often begins as young as age fifty-five. Essentially all pension plans encourage retirement by age sixty-five. The financial incentives in pension plans and their significant effects on retirement have been the subject of an established literature in economics. ${ }^{1}$ Largely absent from the literature, however, is any clear analysis of why firms have designed pension plans this way. To the extent that firm motivations are addressed, a common theoretical assumption is that the incentives are deliberate business policy decisions designed to induce retirement among older workers who are paid more than their productive value. ${ }^{2}$ However, this assumption is made without any evidence from the companies that have implemented the plans. It may also be true that firms are largely unaware of the complex financial incentives in their pension plans, and that they have designed

Richard Woodbury is associated with the program on aging at the National Bureau of Economic Research.

Financial support for this project was provided by the National Institute on Aging, the Japan Foundation Center for Global Partnership, and the National Bureau of Economic Research.

1. A good summary of this research is contained in Lumsdaine and Wise (1994).

2. The primary theoretical framework for this assumption derives from the literature on "implicit contracts." According to the theory, workers are paid less than their productive value at younger ages, and more than their productive value at older ages - creating an incentive for workers not to change jobs, and to work harder in anticipation of the future reward. Pensions then serve as a means of inducing retirement (or at least reducing the effective compensation) among those older workers who would otherwise be paid more than their productive value. See Lazear (1981). 
their plans for completely different reasons. This study sets out to understand better the motivations of firms in designing pension plans, and why these motivations have resulted in plans that have the effect of encouraging early retirement.

The issue has particular importance in the context of current demographic trends. The average number of years spent in retirement has increased steadily, partly as a result of increasing life expectancy, and partly as a result of younger retirement ages. Between 1950 and 2000, labor force participation rates of older men dropped significantly - from 46 percent to 18 percent among men aged sixty-five and older, and from 87 percent to 68 percent among men between ages fifty-five and sixty-four. Among women, the large increase in labor force participation at younger ages is absent at older ages, suggesting the offsetting decision to retire earlier among women as well. The financial incentives in pension plans are an important factor affecting trends in retirement behavior, and inducing earlier retirement decisions. To the extent that these early retirement decisions are made based on distorted (or unintended) economic incentives, they may represent losses in both labor productivity and social welfare that will only grow larger as the population ages.

The study is based on the experience of twenty large U.S. corporations. The analysis draws in particular on a series of discussions about policy history and objectives with executives at each company, and a review of internal business documents relating to the design of the policies. In the case of some of the companies, several days were spent visiting the corporate headquarters, meeting with corporate personnel (including human resource executives, financial affairs executives, and employee benefits planners and administrators), and reading through business documents. Confidentiality of the companies and the executives participating in this study was critical in completing this research effectively, so that they would feel comfortable sharing internal business documents and discussing candidly their underlying business motivations.

The analysis identifies a number of objectives and motivations for the design of business retirement policies, including, in some cases, the desire for older workers to retire. In most cases, however, retirement incentives were either unintentional or secondary to the policy's central motivation. In general, the companies were much more concerned with providing competitive retirement policies (policies similar in structure and in value to those of their competitors in the labor market), and policies that adequately provided for the well-being of their retirees. The design and ongoing evaluation of the policies were targeted primarily toward monitoring the retirement policies offered by competitors, and assessing the adequacy of their own policies in satisfying (but not exceeding) the income replacement needs of their retirees. 


\subsection{The Retirement Policies at Twenty Companies}

Twenty companies were selected to participate in this study. Although the twenty companies are not a random sample, they include companies from a variety of industries: financial services (four companies), hightechnology manufacturing (four), other manufacturing (four), communications (two), retail sales (two), publishing (one), pharmaceuticals (one), consulting (one), and education (one). Their sizes ranged from 2,500 employees to over 100,000 employees. Six of the companies employed between 2,500 and 5,000 workers; six employed between 5,000 and 20,000 workers; four employed between 20,000 and 40,000 workers; and four employed more than 40,000 workers. Nothing was known about the retirement policies used by these companies before their being selected to participate in the study.

Of the twenty companies, thirteen provided the same retirement benefits to all employees; five had two categories of employees, each with a different package of retirement benefits; and two had a large number of different employee groups, each with different retirement benefit programs. In both of the latter cases, however, one retirement benefit package applied to a majority of the company's employees. Thus, excluding the smaller benefit programs at companies with large numbers of different programs, twentyfive different retirement programs are represented in the sample.

All of the twenty-five employee groups participated in either a defined contribution (DC) plan or a defined benefit (DB) plan as their primary retirement income program. For twenty of the groups, the primary retirement income plan was a DB plan. For the other five groups, the primary retirement plan was a DC plan, although two of those five implemented their DC plans to replace older DB plans. Sixteen of the twenty employee groups with DB plans were also eligible for company contributions to a supplementary savings plan, usually with employers matching a specified percentage of each employee's contribution. Twenty of the twenty-five employee groups received postretirement medical benefits.

While the plans differ in detail, all of the DB plans encouraged retirement at older ages. The pension plan at company no. 20 illustrates the characteristics and complexity of the arrangements. The plan provided a "full" pension benefit of 1.5 percent of final average salary per year of service, less a Social Security offset of 1.5 percent of the Primary Insurance Amount per year of service. Employees could be credited with no more than thirty-five years of service; the Social Security offset could not exceed 50 percent of the Primary Insurance Amount; and final average salary was based on the highest five consecutive years. Employees could retire with this "full" pension amount at age sixty-five. With fifteen years of service, however, employees could retire with full benefits at age sixty- 


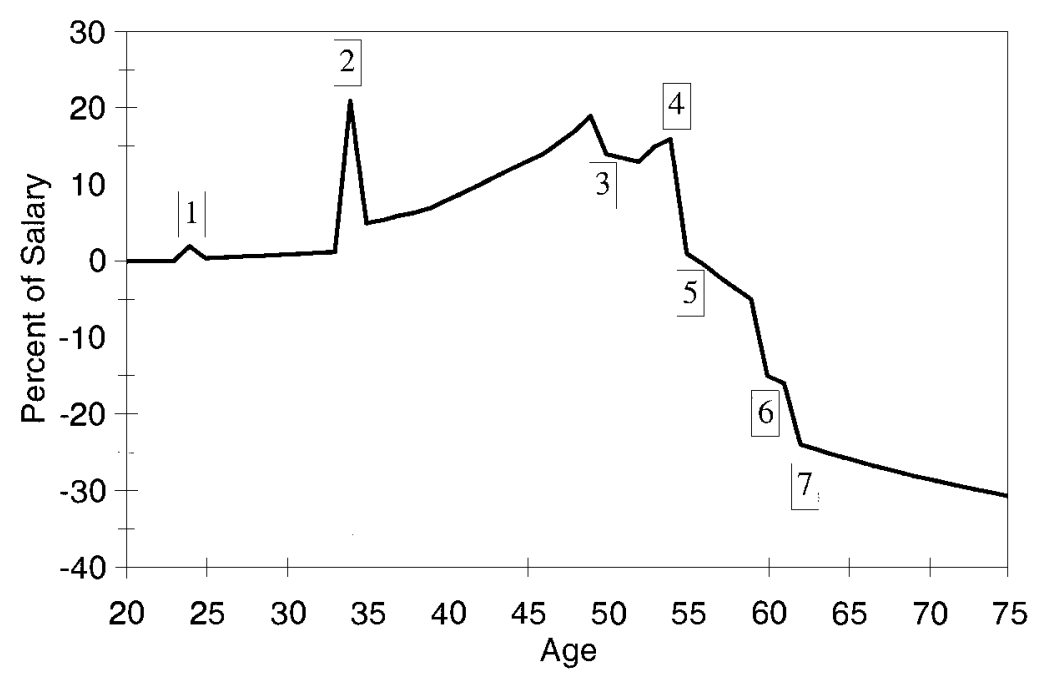

Fig. 10.1 Compensation value of pension plan, employee hired at age twenty

two, or with reduced benefits any time after age fifty. The reduction in the benefit rate for early retirement was 2 percent for each year between the ages of sixty and sixty-two, and 4 percent for each year between ages fifty and sixty. Thus, any employee hired by age thirty-five could retire with 56 percent of the normal pension formula at age fifty, 60 percent at age fiftyone, and so on, up to 96 percent at age sixty, 98 percent at age sixty-one, and 100 percent any time after age sixty-two.

The retirement incentives associated with DB plans are best illustrated by calculating the compensation value of the plan to employees at various ages. The compensation value of a plan is the incremental change in the present value of accrued future pension benefits that results from continued work. The compensation value of the plan at company no. 20 is illustrated in figure 10.1 for a hypothetical employee, with a standard wage history, hired at age twenty. The plan provisions cause numerous discontinuities in this compensation profile, represented at points (1) to (7) in this figure.

1. At age twenty-five, after five years of employment, the employee becomes vested in the plan, and is credited with five years of service. The value of the pension is small, because of the lower salary early in a career.

2. At age thirty-five, after fifteen years of employment, the employee has accrued enough years of service to be eligible for the early retirement payment options. At this point, the employee can leave the company and still receive a pension at age fifty (the early retirement age), rather than at age sixty-five (the normal retirement age). 
3. At age fifty, the employee can retire from the company and begin receiving his or her pension. At this point, continuing to work involves giving up a year of pension income, which partially offsets the increase in the future benefit rate that would be paid by continuing to work.

4. At age fifty-three, the maximum Social Security offset has been attained, so that continued work raises the future benefit without raising the future Social Security offset.

5. At age fifty-five, the maximum thirty-five years of service has been attained, so that continued work no longer increases the years of service credited toward the future pension.

6. At age sixty, the delayed retirement adjustment changes from 4 percent per year to 2 percent per year.

7. At age sixty-two, the delayed retirement adjustment is eliminated, as the employee is now eligible for the full pension. At this point, continued work involves giving up a year of pension income with no increase in years of service credited and no delayed retirement credit. For this employee, the value of the pension plan has dropped from about 15 percent of salary between ages forty-five and fifty-four to -25 percent after age sixty-two. This represents a sharp decline in total compensation that induces substantially more retirement than would occur with an age-neutral pension plan.

Although the plans differ in their details, each of the defined benefit plans provided by the employers in this sample had an economic structure broadly similar to that of the plan at company no. 20. Figure 10.2 illustrates the average compensation value of all of the DB pension plans in this sample. In figure 10.2, the calculations are based on three hypothetical employees with standard wage profiles, hired at ages twenty, thirty-five, and fifty, respectively.

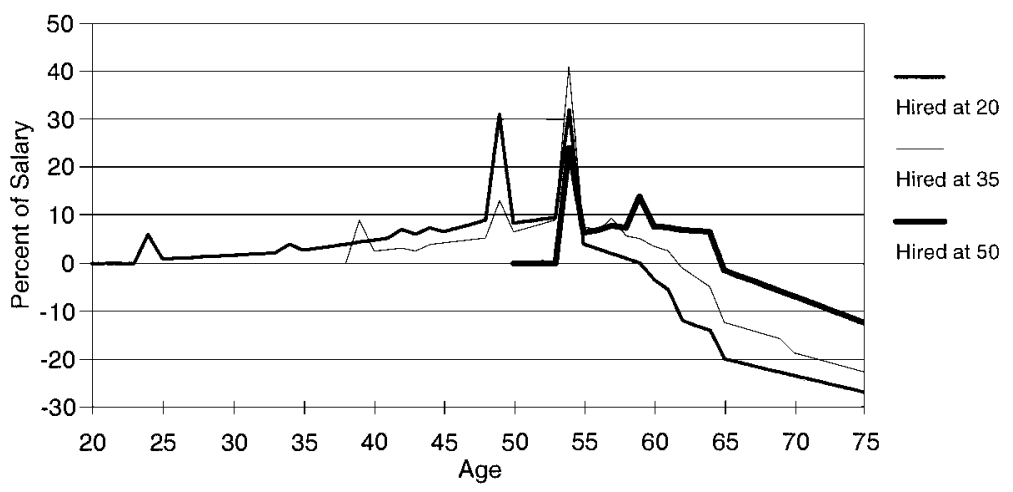

Fig. 10.2 Average compensation value of all pension plans, employees hired at ages twenty, thirty-five, and fifty 
As shown, the average compensation value of the plans increases with age until workers are about fifty-five (a common age of early retirement eligibility), and then declines rapidly thereafter. The average compensation value of the plans becomes negative by age sixty for the very long service employee, by age sixty-two for the employee hired at age thirty-five, and by sixty-five for the employee hired at age fifty. Thereafter, the pension plan loses value, and thus represents a work-related cost rather than a work-related benefit. By age sixty-five, this cost is usually a significant percentage of one's salary.

Retirement incentives are also an implicit aspect of the postretirement medical plans, which were provided by fifteen of the twenty employers in the sample. These policies generally extended the employee's preretirement medical insurance through age sixty-five, and then provided a Medicare supplement policy after age sixty-five. Employees who had completed a minimum service requirement (usually ten years) were generally eligible to receive postretirement medical benefits if they remained employed through the early retirement age.

At companies that provide postretirement medical coverage, there is a sharp decline in the compensation value of firm health benefits, much like the decline in compensation value in pension plans. Firm health insurance benefits have a positive and increasing compensation value up to the early retirement age. (Their value increases due to increasing health risks as individuals age.) At the early retirement age, however, employees immediately accrue the full value of all future medical benefits. Thereafter, there is no compensation value in the plan, since medical benefits are provided regardless of employment status - so the incentive structure of such policies is to provide a large compensation reward for staying through the early retirement age, and then no compensation value thereafter. This decline in compensation value reinforces and increases the magnitudes of the incentive structures of the pension plans at most of the companies in this study.

In summary, the majority of the companies in this sample provided both DB pension plans and postretirement medical benefits, both of which have rapidly decreasing compensation values at older ages. It is not uncommon for the value of these benefits to change over a very short period, from a supplement of 20 percent or more of salary to a cost of 20 percent or more of salary. This induces substantially more retirement than would otherwise take place.

\subsection{Retiree Welfare as a Company Objective}

In discussing the design of their retirement policies, most of the executives participating in this study referred to "caring about retirees," "moral responsibility for retirees," "social responsibility for retirees," "social conscience," or some other expression of paternalistic company values. From 
the perspective of many executives, retirement benefits were viewed more as entitlements for retired employees than as compensation for working employees. The following comments and excerpts from company reports are representative of the views expressed by many of the company executives interviewed about their policies:

We publicize our retirement plans extensively among our employees, so the cost of the policies has the best chance of paying off. But even if they don't pay off, and they probably don't, we feel it's our responsibility to provide the policies anyway. [Company no. 6] is very paternalistic. (Interview at company no. 6)

In its role as a major corporation in our industrial society, [company no. 15] recognizes a responsibility and obligation to its employees to provide income for those years after an employee ceases active employment because of retirement. (Report from company no. 15)

[Company no. 18's] new paternalism means: providing a safety net for retirees' needs. (Presentation slide at company no. 18)

The retiree benefit programs . . . demonstrate [company no. 20's] continuing concern for the well-being of its retirees. (Report from company no. 20)

The practical application of paternalistic values in the design of pension plans is most clearly represented in the widespread use of explicit income replacement targets for retired employees. The idea behind income replacement targets is to identify the percentage of preretirement income that the company believes will provide an appropriate standard of living in retirement. The specificity of the income replacement targets varied across companies. Company no. 2 specified a postretirement income replacement target (including Social Security) of 55 percent of preretirement income for employees with at least thirty years of service. Company no. 4 had an income replacement target of 65-70 percent for employees with thirty years of service. Company no. 16 had an income replacement target of 75 to 80 percent for employees with twenty-five years of service. Company no. 19 had an income replacement target of 67 percent for employees with thirtyfive years of service. Other income replacement targets, such as those shown in table 10.1, varied by income, marital status, and service tenure.

While the specific income replacement targets varied across companies and across groups of employees within companies, the important point is that companies adopted income replacement targets at all. Concerns about retirement standard of living, retiree welfare, and income replacement suggest a very different view of retirement benefits than as components of compensation designed to achieve labor market objectives for working employees.

Other aspects of company policy further demonstrate concern for retiree welfare. For example, many companies have implemented ad hoc increases in the pension payments of retirees to compensate them partially for in- 
Table 10.1

Income Replacement Targets

\begin{tabular}{|c|c|c|c|c|}
\hline & \multicolumn{2}{|c|}{ Income (\$) } & Single & Married \\
\hline \multicolumn{5}{|l|}{ Company no. 20} \\
\hline \multirow[t]{6}{*}{1980 report } & \multicolumn{2}{|c|}{6,500} & .79 & .86 \\
\hline & \multicolumn{2}{|c|}{10,000} & .73 & .78 \\
\hline & \multicolumn{2}{|c|}{15,000} & .66 & .71 \\
\hline & \multicolumn{2}{|c|}{20,000} & .61 & .66 \\
\hline & \multicolumn{2}{|c|}{30,000} & .58 & .60 \\
\hline & \multicolumn{2}{|c|}{50,000} & .51 & .55 \\
\hline \multirow[t]{6}{*}{1989 report } & \multicolumn{2}{|c|}{20,000} & .62 & .82 \\
\hline & \multicolumn{2}{|c|}{40,000} & .56 & .75 \\
\hline & \multicolumn{2}{|c|}{80,000} & .47 & .63 \\
\hline & \multicolumn{2}{|c|}{150,000} & .46 & .62 \\
\hline & \multicolumn{2}{|c|}{300,000} & .38 & .50 \\
\hline & Pay Level & Full Career & Partial Career & Short Service \\
\hline \multicolumn{5}{|c|}{ Company no. 18} \\
\hline \multirow[t]{3}{*}{1977 report } & Low & .74 & .67 & .56 \\
\hline & Medium & .61 & .51 & .39 \\
\hline & High & .45 & .37 & .29 \\
\hline
\end{tabular}

creases in the cost of living. The additional expenses associated with ad hoc increases have been incurred, even though the companies have had no legal obligation to make them. The reason given for these benefit adjustments was that high inflation rates had placed a particular hardship on retirees, and that companies were concerned about the welfare of these retirees.

Concern for retiree welfare also motivated many of these firms to credit the years of service performed by employees before the implementation or improvement of a plan. Again, the motivation for this retroactive compensation seems based on a paternalistic concern for retiree welfare. A report outlining new pension benefits at company no. 15 clearly expresses this philosophy:

It became obvious that the magnitude of the problem of prior service and its potential cost required detailed and careful analysis.... This Committee can see no valid reason, except possibly for cost, why the Philosophy and Objectives set forth should not apply to those persons who are nearing the end of their career as well as those just embarking on their careers. Thus, the improvement of benefits already accrued would not only seem a valid objective, but has an immediacy which dramatizes its importance.

Another policy decision made by most companies has been to provide (or at least subsidize) medical benefits for the spouses and dependents of retired (as well as active) employees. Again, these additional expenses were incurred even though there was no legal obligation to provide them. And 
again, concern (or responsibility) for employee and retiree welfare was the justification made by business executives. According to a report at company no. 20, "the benefit design reflects [company no. 20's] belief that it is the company's responsibility to provide protection for a retiree's dependents as well as for the retiree."

\subsection{Paternalism and the Design of Retirement Policy}

Having identified retiree welfare as a key motivating objective in the design of retirement policies, one then asks why the resulting policies have the effect of inducing retirement. This section provides some evidence on how these motivations were translated into policies with particular characteristics.

The typical business perspective on plan design had the following components:

1. Defined benefit plans, by providing an explicitly defined stream of retirement income, are thought to be more consistent with paternalistic company values than are DC plans, which have no future income assurances.

2. There is a sense that any employee who has committed a full career of service, as defined by years of employment, should be entitled to retire with the support of the company. Thus, a thirty-year employee, for example, should be entitled to health insurance and an adequate pension, whether he or she chooses to retire at age fifty-five or age seventy-five.

3. Pension payments should not be larger than what is necessary to maintain one's preretirement standard of living.

It turns out that these three motivating considerations have led to policies with implicit retirement incentives, even though the retirement incentives were not even considered when the policies were being implemented.

Among companies with DB plans, executives expressed the value of an assured level of retirement income that would enable career employees to retain their preretirement standards of living. The benefit formulas could be calibrated to any targeted level of income replacement. Formulas integrated with Social Security (like those used by most of the companies in this study) could be calibrated even more precisely to total income replacement objectives. For this reason, DB plans were often viewed as preferable to DC plans.

Of course, a company's choice of a DB plan (rather than a DC plan) need not imply an economic structure that encourages retirement. One could actuarially adjust the benefit rate to account for different retirement ages, so that the financial structure would be age neutral. However, this would lead to very different income replacement rates among those retiring at younger ages, as compared with those retiring at older ages. Either 
the early retirement benefit would be too low for career service employees whom the company wants to support fully in retirement; or the normal and late retirement benefits would be higher than what is considered an appropriate retirement pension. The resulting decisions about how to treat early and late retirees has led to pension plans with implicit retirement incentives such as those summarized in section 10.2. The following excerpts from company reports illustrate some of these concerns, including the decision to limit the years of service credited in many plans:

(a) With regard to age, we saw no rationale for maintaining that a 66 year old employee deserved a higher level of income replacement from the Company than a 65 year old with the same amount of credited service. (b) Specifically, it was felt that [company no. 15] should not allocate its resources to provide more than $100 \%$ replacement of pre-retirement disposable income.

This issue with regard to length of service greater than the full career benchmark is more complex inasmuch as one could maintain that employees with greater longevity are entitled to a greater level of income replacement solely because of that longevity. The Task Force's consensus, however, was that the proposed income replacement goals are a reasonable measurement of [company no. 15 's] share of the total responsibility for providing post retirement income replacement. . . It should not be necessary to spend money in order to provide levels of income replacement beyond these goals. For this reason, it was determined that a maximum limitation on the accumulation of credited service was needed to prevent the over-provision of benefits to those employees with service longer than the 30-year full career benchmark. (Report from company no. 15)

Studies show that if the pension benefit plus Social Security benefit exceeds more than 83 to 85 percent of final pay-[the] employee will have more after-tax dollars in retirement than while working. ... [We are concerned] that future improvements in the pension plan will result in the sum of [company no. 7's] pension plan plus Social Security providing more than take home pay in some cases. (Slide at company no. 7)

The same way of thinking applies to postretirement medical benefits. Once an employee has had a service history long enough to become a responsibility of the company, then the full postretirement medical benefit has been provided, whether the individual chooses early, normal, or late retirement. Again, there is an implicit retirement incentive in this approach that has nothing to do with the paternalistic intent of the plan design.

In summary, companies expressed a great deal of concern for the wellbeing of their retired employees. This concern motivated the provision of retirement policies designed to provide an acceptable (but not excessive) standard of living to all long-service employees during their retirements, regardless of the age when retirement took place. Policies satisfying these 
paternalistic objectives implicitly contain retirement incentives, even though the incentives were not at all the primary motivation for the policy design.

\subsection{Policy Competitiveness}

Competitiveness was expressed as the other central motivation for the implementation and design of retirement policies at most companies. Companies spend considerable resources monitoring the retirement policies provided by competing employers and comparing those policies with their own. Benefits consultants assist companies in maintaining current information about the policies being provided by their competitors, and in making comparisons among the policies at different companies. In some cases, companies develop very explicit competitiveness targets much like the income replacement targets described above:

We position pension benefits on the basis of comparative studies with major industries, and such comparisons are based upon current survey data. Market relationships based on these studies change over time and we need the ability to take into account such movements. (Report from company no. 7)

Specifically, it is [company no. 9's] objective to provide retirement benefits to a typical employee ... which places us at the 50th percentile of benefits payable from a large group of 250 U.S. based manufacturing companies. The income replacement of these benefit levels is higher for lower paid people than it is for higher paid people. (Report from company no. 9)

An examination of the table in Appendix A will disclose that there is room for improvement in our competitive posture for normal retirement benefits. At the $\$ 70,000$ income level, the Salaried Plan ranks 17 th out of 38 companies, or in the lower end of the third quartile. The income replacement level exactly matches the mean. [Company no. 15] ranks $22 \mathrm{nd}$, or at the bottom of the second quartile at the $\$ 30,000$ income level and 35 th - well within the lowest quartile - at the $\$ 15,000$ income level. (Report from company no. 15)

Desired Competitive Position (quartile ranking relative to competing companies)

\begin{tabular}{llllll}
\hline & \multicolumn{5}{c}{ Retirement or Termination Age } \\
\cline { 2 - 6 } Years of Service & 65 & 62 & 55 & 45 & 35 \\
\hline 35 & $1 \mathrm{st}$ & $1 \mathrm{st}$ & $1 \mathrm{st}$ & - & - \\
25 & $1 \mathrm{st}$ & $1 \mathrm{st}$ & Median & $3 \mathrm{rd}$ & - \\
18 & Median & Median & Median & $3 \mathrm{rd}$ & - \\
10 & 4 th & 4 th & 4 th & 4 th & 4 th \\
(Report from company no. 18) & & & & \\
\hline
\end{tabular}


The retiree benefit program is designed to be generally competitive within the ... industry. (Report from company no. 20)

The implication of these concerns is that company policies tend to evolve together. Because each company is continually monitoring the policies of competitors in the labor market, there is a strong tendency to create policies with a similar structure and a similar value. Considering this in historical context, the leading large companies in the United States established retirement plans thinking largely about retirement security for their career-service employees. This approach then became the model from which other companies needed to compete. Thus, many more companies subsequently implemented traditional DB pension plans, not because of their retirement incentive effects, nor because of their concern for retiree welfare, but because it became the standard for major U.S. employers.

The development of retirement plans at companies no. 2 and no. 8 supports this perspective. Both companies began with no retirement benefits and with a comparatively young labor force. According to executives at each company, as workers got older, they became more interested in retirement and, consequently, more interested in retirement benefits. Observing the retirement benefits provided to employees at other companies, employees at companies no. 2 and no. 8 began to request similar benefits for themselves. Responding to these requests, company no. 8 implemented a DB plan in the mid-1970s, and company no. 2 implemented a similar plan in the late 1970s. The plans were selected because they were similar to those offered by other large employers. Since both companies were expanding rapidly during this period, inducing retirement was almost certainly not the motivation for the plan design. According to executives at these companies, there were no specific objectives in designing their pension plans other than to satisfy their older workers by offering a standard plan.

In some cases, companies have revised their policies to provide larger early retirement incentives, not because they have wanted to encourage earlier retirement, but because they have wanted to remain competitive. An executive at company no. 19, for example, suggested that his company was considering a revision to the pension plan for this exact purpose:

We have a program that asks for employee recommendations about the business. It's a program called "[company no. 19] listens." Lately, we have had a lot of requests for larger early retirement benefits. Employees are pointing out other companies that have more generous early retirement benefits, and they think [company no. 19] ought to have those benefits, too.

In summary, many companies choose their retirement policies to be similar in structure and in value to the retirement plans offered by competing companies. Defined benefit pension plans and postretirement medical plans have historically been the standard for large employers in the United 
States. Over time, many companies have implemented similar plans. In almost every case, the incentive effects of the policies have been irrelevant to their design.

\subsection{The Role of Work and Retirement Incentives}

The interviews conducted at each of the twenty companies in this study generally began with a deliberately broad inquiry about the history of the plans, the motivations and objectives of the plans, and the reasons for their particular plan-design decisions. Much later in the interviews, after fully exploring the issues raised by company executives independently, the topic of work and retirement incentives was introduced explicitly. Inducing retirement was almost never suggested as a plan motivation during the openended parts of the interviews. Reactions to the idea that the plans might encourage retirement varied considerably - first, in the extent to which the incentives were even recognized, and second, in the extent to which they were considered a desirable outcome of the policies. Those most familiar with the incentive effects of the plans were at companies that had implemented temporary early retirement incentive plans (window plans) as a means of downsizing their total employment.

Overall, companies expressed varying degrees of recognition and attributed varying levels of importance to the work and retirement incentives associated with their policies. In reference to retirement before the normal retirement age and before Social Security eligibility, it was quite common for executives to discount the importance of retirement incentives. At company no. 2 , it was suggested that there were no particular retirement incentives in the policies, because "most people can't afford to retire before they become eligible for Social Security and Medicare." At company no. 9, it was suggested that "retirement incentives and the trend toward earlier retirement are a non-issue here." An executive at company no. 18 recognized_-"mathematically" — that the company's pension plan made less than actuarially fair increases in the pension benefits of employees delaying retirement after the early retirement age; this executive argued that few employees could afford to retire before Social Security eligibility, so that the mathematical calculation was not relevant to retirement behavior at company no. 18. At company no. 20, a plan report stated that "the benefit design encourages early retirement" and that "the full availability of medical benefits in early retirement further encourages early retirement," yet an executive at the company discounted the importance of early retirement because "people can not afford to live on their company benefits alone."

A comment from the top human-resource executive at company no. 9 is representative of the way most business executives viewed the financial characteristics of their plans. The comment was made after the person heard an economic explanation of how pension accrual varies with age: 
The company's labor cost doesn't change when a person reaches age fifty-five or age sixty-two. The cost of the pension plan gets averaged out over all employees. We look at it in a very aggregate way. ... Your argument might be right, technically, but it's not how we do it at [company no. 9].

The tendency to look at the aggregate cost of the retirement plans per employee (or the cost as a percentage of payroll) was evident at most companies. None of the companies interviewed had calculated the accrual pattern of future retirement benefits (the compensation value of the plans) for individual employees, as has been done extensively in economics studies. Thus, the views executives offered about retirement incentives were quite general, rather than quantitatively specific.

In reference to retirement incentives after the normal retirement age, most executives did acknowledge that their policies (along with public retirement policies) probably encouraged retirement, and that this was probably a desirable outcome. While inducing retirement was not considered a key motivation for the design of the policies, most executives were not unsatisfied with the overall retirement behavior of their labor forces.

The extent to which retirement at older ages was viewed as desirable varied across companies and, frequently, across executives within companies. For example, in a series of interviews at company no. 15, one executive argued that it is good for workers and good for the company if people retire between ages fifty-five and sixty, two other executives argued that the company was essentially indifferent to when workers retire; and a fourth executive was referenced arguing that it would be best if workers never retired. While the interviews at most companies elicited less diversity of opinion, the tone in which opinions were expressed was similar at most companies. They were offered as just that-opinions. They were neither company decisions nor company policies, but individual executives thinking through the desirability of retirement at older ages, and offering their personal judgments. Both the diversity of opinion and the tone in which opinions were offered reinforce the idea that influencing retirement behavior was not a primary motivation for the policy design.

Numerous opinions were expressed on the desirability of retirement, many of which parallel reasoning used in the economics literature. Some suggested that salary increases over a working career have resulted in older workers' being paid more than their productive value. In many cases, younger workers were thought to be as effective or almost as effective as older workers, but at a lower cost. Some executives also suggested that the productivity of labor declines at older ages. Company no. 1 suggested that older workers do not cope well with change. Company no. 5 suggested that one major class of its employees needs a great deal of energy to do their jobs well, and that older employees often lack this energy. Companies no. 6 and no. 7 suggested that many of their employees are engaged in physically 
demanding jobs that are too strenuous for older employees. An executive at company no. 15 suggested that workers become less flexible, less energetic, and less knowledgeable about new skills and techniques as they age.

In addition to these arguments about individual compensation patterns and productivity patterns, some executives argued that the business environment benefits from retirement. According to an executive at company no. 14, the morale, retention, motivation, and productivity of younger workers depends on their having opportunities for advancement, and retirements create these opportunities. According to an executive at company no. 15 , the regular turnover of older workers also enables companies to hire new workers with new skills and new ideas, the steady flow of which is essential for a productive business environment.

A number of executives also offered some good explanations for why retirement incentives should be applied through retirement benefits rather than through wage reductions or layoffs. For example, age discrimination laws prevent the use of layoffs, terminations, or wage reductions that disproportionately affect older people. By contrast, retirement benefits are praised as corporate generosity. According to an executive at company no. 6, "Cutting the wages of older people would be bloody. . . Layoffs create ill will. . . . Generous retirement benefits create good will."

It is clear that every company has some older employees that they would prefer to keep employed for many years in the future, and other older employees that they wish had retired years earlier; but it is essentially impossible to apply compensation arrangements selectively to some employees and not others. Executives at companies no. 1 and no. 16 suggested the use of retirement policies as a device for screening older workers. Unproductive employees are then eliminated (retired) permanently, while productive employees are hired back on an hourly or consulting basis (at no cost to their ongoing pension benefits). While all employees are eligible to participate in the hire-back programs at these companies, only the productive older workers are encouraged to participate.

These interviews give one the sense that company executives were generally satisfied with a compensation system that leads to retirement at older ages. The precise age-specific incentive structure of the plans was rarely if ever considered in the design of the plans-but their role in inducing retirement was not inconsistent with what companies seemed to view as desirable to business dynamics.

\subsection{Retirement Incentives and Downsizing}

The few companies that referred to retirement incentives as a relevant policy motivation tended to have declining or changing employment needs. After declining sales, changes in production technology, or changes in product composition, some companies want to reduce the number of ac- 
tive employees on their payrolls, or to encourage greater turnover among employees with unneeded skills. Inducing retirement among older workers has been an important alternative to layoffs in achieving these workforce management objectives. The reasons suggested for using retirement incentives, rather than layoffs, relate to their public acceptance. Early retirement benefits are viewed as acceptable and even generous, whereas layoffs are viewed as unpleasant and insensitive to employees.

Unlike the permanent retirement policies discussed above, window plans are quite explicitly designed to encourage retirement among older workers. A report at company no. 15, for example, includes the following justification for a window plan at one of its divisions:

The proposed voluntary early retirement incentive program is part of a plan developed by [division] to produce a downsized, more efficient organization. This plan was developed due to a $42 \%$ decline in net aftertax profits from 1983 to the 1985 midyear estimate, a decline which has been attributed to industry overcapacity and severe price competition.

Because window plans are explicitly designed to induce retirement, executives at companies that have used window plans have gained a great deal more appreciation for the capacity of retirement policies to influence retirement behavior. Thus, when these executives discussed the motivations for their retirement policies-broadly defined-they were more likely to include retirement incentives as a relevant policy motivation. What is different about these companies is the greater awareness and appreciation of the retirement incentives that already existed in their regular retirement policies, rather than any differences in the original motivations for their policies.

The experiences of companies no. 5 and no. 7 exemplify both the role of retirement policies in the transition process and the resulting appreciation for retirement policy incentives. Both companies experienced major technological innovations in their production techniques. Because of these innovations, the skills of most of their workers were no longer necessary in the production process, and the total number of workers needed was smaller.

At company no. 5, the decline in employment needs was almost entirely among the unionized workers. This presented a particular challenge for management at company no. 5 , since the unions placed a high value on job security. The challenge was compounded because different unions had claims on different parts of the production process. If union 1 had a claim on production process $\mathrm{A}$, then no non-union 1 employees were allowed to contribute to process $\mathrm{A}$, and no union 1 employees were allowed to do anything but process $\mathrm{A}$. Because of the priorities and strengths of the unions, neither layoffs nor retraining were as attractive to the company as retirement incentives. Executives believed that it would be less costly for the company to fund enormous retirement incentives rather than to fight 
the unions. Thus, a considerable portion of company no. 5's downsizing was accomplished through window plans, many of which provided almost as much money for retiring as for working.

There was a big technological change in the . . industry, and we had to negotiate automation with the unions. At the same time, the unions wanted a lifetime job guarantee. So retirement incentives have been a very important part of our retirement policies. (Interview at company no. 5)

Company no. 7 also used a window plan to facilitate its transition to a lower level of employment. In addition, company no. 7 implemented new "permanent" pension plans for management and nonmanagement employees. What is particularly interesting about the experience of company no. 7 is its explicit reference to retirement incentives in the design of the new permanent plans. According to an executive at company no. 7, the new pension plans were deliberately designed to require periodic updates, partly so that the company could respond to changing business conditions. Specifically, benefit values were set at fixed dollar amounts that depreciated in real terms over time. Plan updates could be implemented deliberately at times when management would like more retirement to occur. Part of the effectiveness of this approach resulted from changes in employee expectations. Since the updates became a standard and well-understood provision of the plans, many employees learned to defer retirement until just after a plan update. This provided an even greater ability for company no. 7 to retain employees by deferring a plan update or to encourage retirement by implementing a plan update.

For some companies, retirement incentives have provided an important alternative to layoffs in reducing employment and encouraging worker turnover. Moreover, the increasing use of window plans has increased the awareness among business executives of the capacity for retirement policies to influence retirement behavior.

\subsection{Plans without Retirement Incentives}

A few of the companies participating in this study diverged from the "standard" approach to retirement policy. Companies no. 1, 3, 10, 11, and 17 had no retirement incentives in their pension plans for at least one category of employees. Defined contribution pension plans were the primary retirement policy for these employee groups. Two themes characterize the explanations for the plan design at these companies. First, these companies tended to prefer the immediate distribution of employee benefits, rather than deferred distribution. Second, the employee relations strategy used by these companies was more often oriented toward performance and productivity monitoring rather than paternalistic support.

Immediate distribution was considered valuable from the perspective of 
both employer and employee. According to executives at these companies, a retirement account that is denominated and maintained for each employee individually is more tangible during the employee's working years than is a future pension entitlement. The employee can see that a particular asset has been set aside in his or her name and for personal use in retirement. This tangibility creates a greater sense of wealth or value to the employee than the value conveyed by a defined benefit plan. The popularity of primary DC plans was emphasized at all of the companies offering them.

The financial predictability of DC plans was another factor suggested among employers choosing them. An executive at company no. 11, for example, argued that the certain cost associated with DC plans enabled more accurate cost monitoring, and thus better business decisions. At company no. 17 , it was suggested that the company had very little physical or financial capital, and thus could not afford to assume any large financial risks. Defined benefit plans have an implicit risk to the company, since the company is obligated to pay a defined pension amount regardless of the investment performance of the pension fund.

While it is impossible to generalize about the characteristics of companies choosing one approach or the other in this small sample, the choice of a DB or DC approach seems to be associated with a broader choice of employee relations strategy. Some companies motivate workers through direct productivity incentives, carefully monitoring employee performance, and rewarding high productivity. These companies tend to like DC plans with no future promises. Other companies motivate workers indirectly through expressions of paternalistic support. These companies tend to like DB plans and postretirement medical plans that are designed to insure the long-term well-being of long-service employees. Executives at two companies referred directly to these differences in strategy.

Some industries, like the chemical industry, are very gentlemanly. Other industries, like the high-tech industry, are dog-eat-dog. (Interview at company no. 2)

Different companies use different strategies in their relationship to employees. IBM uses a soft approach, trying to elicit good worker morale by never firing workers. [Company no. 11] uses a performanceoriented approach in which unprofitable divisions are rapidly changed. (Interview at company no. 11)

At the companies choosing DC plans, productivity monitoring on the employee and business-unit levels was suggested as a critical ongoing aspect of employment. At company no. 1, it was only the commissioned employees who participated in the DC plan, and their entire compensation was based on productivity. At companies no. 3, 11, and 17, annual wage adjustments were based on careful and detailed worker performance analyses; workers receiving poor evaluations were routinely terminated. At 
company no. 11, unprofitable subdivisions of the company were quickly redesigned or closed. Companies following this aggressive, performanceoriented strategy considered their retirement benefits as components of current compensation for worker productivity. The immediate distribution and certain cost of DC plans make them more consistent with a performance-oriented approach.

While this study includes too few companies to draw any systematic conclusions about the determinants of policy variability across companies, the interviews suggest that many policy decisions are not carefully conceived, and are, to a significant extent, arbitrary. Based on the few companies participating in this study, the idiosyncratic preferences of chief executive officers (CEOs) seems to dominate any observable company characteristics. Although no CEOs were interviewed for this study, discussion with other executives suggests the overwhelming influence of CEOs at many companies, and the apparent arbitrariness of many of the decisions made.

We boil up ideas, but the Chairman comes through with the tablet. . . Top management just likes defined benefit plans. They think defined benefit plans are what retirement policy should be. They have a perception that this is what [company no. 6] owes its retirees. (Interview at company no. 6)

Most companies don't have any great philosophy. Senior management just likes a defined benefit plan. They think it's "right." (Interview at company no. 8)

[The CEO] started this company and we hear a lot of stories about when the company was small: how people gave up a lot, and how we owe them for it. He believes that we should take care of retired employees. (Interview at company no. 18)

I don't know about other companies, but this CEO is involved in everything. ... We'll take a proposal to him. He'll ask us 500 different questions about it, and then he'll tell us what he wants. We have no idea what he will decide until we present a proposal. (Interview at company no. 20)

The top managers are older and that has a big influence. They weigh retirement more heavily than a typical worker, and that affects their policy decisions. (Interview at company no. 2)

In summary, companies that appear quite similar can have very different retirement policies, and these differences in policy may not be explained by differences in observed company characteristics. Moreover, because of the many competing factors influencing retirement policy decisions, executives making these decisions can find a reasonable justification for just about any policy selected. In the end, it appears that the idiosyncratic judgments of individual executives guide at least part of retirement policy design. 


\subsection{A Case Study}

One of the companies in the sample conducted a particularly comprehensive evaluation of its pension plans over the period of this study. What is interesting about this case study is the company's explicit objective to design a pension plan that is "neutral relative to the age at which retirement occurs," and the company's subsequent development of a policy proposal that contains retirement incentives anyway.

The policy evaluation was implemented because of a concern among company executives that the value of the benefits from the DB plan and the supplementary savings plans were lower than the values of comparable benefits offered by competing employers. To address these competitive deficiencies, a special committee was appointed to evaluate the then-current policies and to develop a new policy proposal. Two philosophies dominated the evaluation process. First, the company wanted a retirement policy that adequately supported the retirement income needs of retirees. Second, the company wanted a retirement policy that was competitive with those offered by competing employers. A great deal of the committee's time was spent evaluating the relative importance of these two philosophies.

Initially, the primary motivation of the committee was to develop a new policy that would adequately support the needs of retired employees. According to executives at the company, the importance of these company values dated back to the founding of the company, and to the founder's belief that employees should be treated as family. As in past policy evaluations, the company established a series of income replacement targets, calibrated to enable "full career" employees to maintain their preretirement standards of living. The company then compared the replacement rates of the current plans with the target replacement rates. This retirement needs analysis was conducted in some detail, with calculations made for employees with different salary levels, different service histories, and different retirement ages. The primary conclusion of this analysis was that the company's existing policies fell significantly short of their income replacement targets.

As the evaluation process progressed, the company's interest in designing a policy to satisfy retiree needs lost some of its importance, because members of the committee noted the diversity of the company's labor force and the wide variation in retirement needs across employees - and, thus, the inability of the company to choose one right retirement policy (or income replacement rate) for every employee.

The company cannot determine the retirement cash needs of employees since each individual's situation is different. This has been caused by changed workforce demographics, such as the prevalence of dual wageearner families. Therefore, the company should not base the design of 
its retirement programs on the perceived retirement cash needs of an "average" employee. (Presentation slide)

In its place, the company adopted a retirement policy strategy based more heavily on competitiveness in the labor market, and on flexibility to meet a diversity of employee needs:

The company recognizes employees' responsibility to set their own retirement objectives. The company will help employees achieve their objectives by providing automatic and elective retirement benefits as well as education. The value of benefits received by employees and the resulting cost to the company will be driven mainly by competitive positioning and the extent to which employees utilize elective benefits. (Presentation slide)

Thus, competitive positioning became the most important criterion motivating the policy design, and a group of thirty competing employers was selected for comparison. The existing retirement policy was carefully ranked relative to those of the competing companies. The primary conclusion of this competitive analysis was that the company's current retirement policies ranked very low relative to the policies offered by competing employers.

While competitive positioning became the most important policy objective, the committee developed a number of other criteria on which their retirement plans should be evaluated. The final set of objectives included competitiveness objectives, financial objectives, employee education objectives, workforce planning objectives, and employee relations objectives. These are summarized in table 10.2, using language adopted by the committee for a presentation to senior management. Note that under its "Workforce Planning Objectives" the company explicitly referred to a policy that is "neutral relative to the age at which retirement occurs."

These objectives were formally approved by senior management, and the committee was then directed to develop a retirement policy proposal based on these objectives. The committee proposal included a new DB pension plan, and the addition of employer matching provisions to the supplementary savings plan. Figure 10.3 shows the compensation values of the proposed pension plan, by age.

The new plan clearly was not age neutral. According to an executive who worked extensively on the plan evaluation, "there were competing objectives and other objectives were weighed more heavily." In the end, by far the most important factor motivating the policy proposal at this company was a desire to be competitive in the labor market-it had been the competitive deficiency in the existing policy that inspired a policy evaluation in the first place. Then, to address this competitive deficiency, a policy was designed with a similar structure and a similar value to the policies offered by competing companies. Despite the decision to move away from 
Table 10.2

Retirement Policy Objectives

Competitiveness Objectives: The aggregate position of the company's retirement programs should be average; the company should value longer service more than higher age; retirement benefits should be independent of hierarchy ...

Financial Objectives for the Company: Retirement benefits programs must be affordable to the company; provide the company with a predictable financial cost; and provide retirement benefits in the most cost-effective manner.

Financial Objectives for Employees: Provide employees with a predictable financial benefit to help them plan savings for their retirement; provide retirement benefits in the most cost-effective manner to employees; provide retirement benefits with an acceptable level of investment and inflation risk.

Employee Eduction Objectives: The company has a responsibility to ensure that employees understand that they are responsible for planning for their retirement; to provide opportunities for employee education so that they are able to plan for their retirement; to provide a comprehensive set of tools to enable employees to plan for their retirement.

Workforce Planning Objectives: Plan design should be neutral relative to the age at which retirement occurs, but should be flexible to react to business and changing workforce requirements. Plan design must support recruitment and retention of employees with desired skill mix; plan design must support the recruitment of skilled senior employees.

Employee Relations Objectives: Employees believe that the company's retirement programs are valuable, competitive, equitable. Employees believe that the company helps them prepare for retirement.

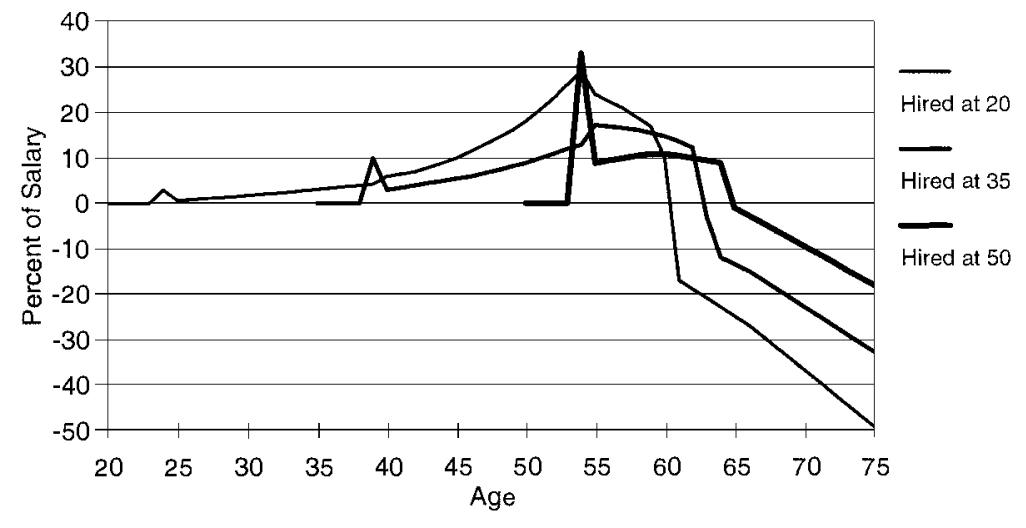

Fig. 10.3 Compensation value of new pension plan, employees hired at ages twenty, thirty-five, and fifty

explicitly paternalistic policy objectives, several executives on the policy review committee emphasized retiree welfare as a long-standing priority of their CEO and as the second-most important motivation in the final plan design. The presence or absence of retirement incentives was a third tier of concern in the evaluation process, and was eventually outweighed by other policy priorities. 


\subsection{Retirement Policy in Transition}

Many of the companies participating in this study evaluated or changed one or more aspects of their retirement policies around the time of the study. First, two companies replaced their DB plans with DC plans, and several others increased their contributions to supplementary retirement saving plans. Second, several companies with DB plans raised the ages of early and normal retirement, and implemented larger decreases in the benefits of those choosing early retirement. Third, several companies eliminated, decreased the value of, or at least questioned the provision of postretirement medical benefits. Table 10.3 lists the policy changes or proposed changes by these companies.

Together, these changes are suggestive of a trend toward policies with fewer early retirement incentives. This results partly from the increasing use of DC plans and other retirement saving plans, relative to that of traditional DB pension plans; partly from increases in the age of eligibility for

\section{Table 10.3 Changes in Retirement Policies}

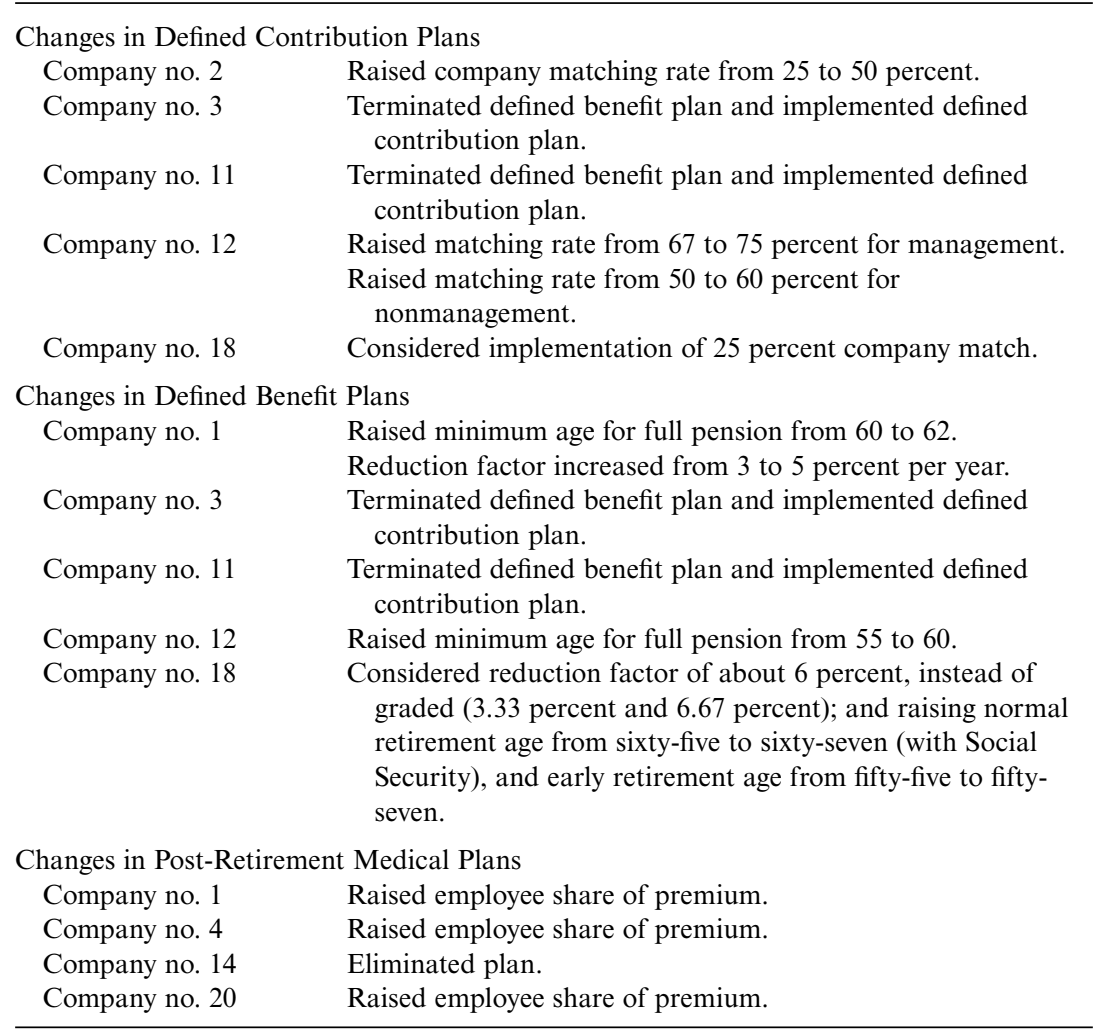


early and normal benefits within the traditional plans; and partly from the decreasing prevalence of postretirement medical benefits.

The consistent explanation for increasing provision of DC and supplementary saving plans was related to their popularity among employees and to the need to remain competitive with other employers who were offering these benefits. An additional explanation for terminating the DB plan at company no. 3 was to gain access to the surplus assets in the pension fund. Other managers of DB plans referred to the growing legal and administrative costs of DB plans in complying with new regulations, and their decreasing desirability for that reason.

At the companies that changed the provisions of their DB plans, inducing employees to defer retirement until older ages has been an important motivation. There was a particular concern at some companies that fewer younger workers would be available in the future to fill the positions currently held by older workers. Though applicable to only a few companies, these comments were the most direct evidence of retirement incentives' having a significant role in policy reform.

The consistent explanations for reductions in postretirement medical benefits was their increasing cost, based on increasing health care costs generally, and the increasing ratio of retirees to employees at most companies.

Overall, the change in the age demographics of the U.S. population seems particularly important in inspiring current trends. At one time, paternalistic retirement policies were inexpensive. Companies could support retirees without a large expenditure of resources because there were many more working employees than retired employees, and because retired employees had shorter life expectancies. Indeed, the employee-relations advantages of being a "caring" company almost certainly exceeded the cost of paternalistic programs. The increasing older population, and the increasing cost of retirement programs, have inspired a growing number of companies to reevaluate their traditional paternalistic values.

A number of companies referred to these changing priorities and, at the same time, to the significant impediments to policy reform. This suggests that the current trend away from DB plans and postretirement medical plans is likely to continue into the future, though the pace of change may continue to be gradual.

The old plan was a remnant of a different era in retirement planning. When the defined benefit plan was implemented, there was no such thing as a 401(k) plan, and defined benefit plans were considered state of the art. In addition, defined benefit plans were satisfactory to employees at that time, because very few other companies offered defined contribution plans. (Interview at company no. 3)

A lot of companies are locked-in to their existing plans. If they could start again, they would choose defined contribution plans, but they al- 
ready have defined benefit plans that are too costly to terminate. First, hourly employees are very suspicious of changes, particularly the "cancellation" or "termination" of a pension plan. Second, defined benefit plans are one of the main selling points used by unions to attract union membership. Unions claim that their protection of defined benefit plans assures that workers will have a decent retirement income. (Interview at company no. 11)

Do you want to convince employees that they are better off without the type of pension plans they are used to, and without the type of plan that is offered by the competitors? Do you want to renegotiate the new retirement plan with thirty unions? Do you want to pay the legal and administrative costs associated with terminating the existing plan, and setting up the new plan? Do you want to figure out how to comply with all of the government regulations associated with terminations? ... As long as no one is complaining about the current plan, it just isn't worth trying to change it. (Interview at company no. 9)

\subsection{Summary and Discussion}

At fourteen of the twenty companies in this study, all employees participated in a retirement policy with incentives to retire at particular ages. At another three of the companies, some categories of employees participated in a retirement policy with incentives to retire at particular ages. Only three companies had retirement policies that did not encourage the retirement of older workers. Despite the widespread use of policies that encourage retirement, the main finding of this study is that retirement incentives are typically not a central motivation for the policy design.

Two motivations have dominated the past design of business retirement policies-concern about retiree welfare, and concern about competitiveness in the labor market. A great deal of the current structure of business retirement policies is based on a history of paternalistic company values. Many executives indicated that their companies had the responsibility to insure the well-being of retired employees and, because of this responsibility, many executives viewed their retirement policies more as entitlements or welfare for retired employees than as compensation for working employees. This view of retirement policies is reflected in pension plans and postretirement medical plans designed to support the needs of retired employees.

The effect of these company values on the economic structure of retirement policies is to encourage retirement. The benefits of those retiring early cannot be reduced too dramatically, or early retirees will be unable to maintain their preretirement standards of living. Similarly, the benefits of those retiring late need not be increased, since their preretirement standards of living can be maintained with normal benefit levels. Thus the retirement policies have an economic structure that encourages retirement, 
even though retirement incentives were not a central motivation in their design.

Business concerns about competitiveness in the labor market have had the effect of spreading these traditional policies more widely through the business community. In order to be competitive, companies have chosen policies with similar structures and similar values to those offered by competing employers. Thus companies without strong paternalistic values have been driven by competitive pressures to implement policies with the same economic structures. Whether the policies at a company were motivated more by a concern for retiree welfare or more by a concern for competitiveness in the labor market, the same policies with the same economic structures and the same retirement incentives have been chosen. In either case, it was not the retirement incentives that motivated the policy design.

A study by Siegel (1990) reaches many of the same conclusions made in this study. Siegel's study focuses on the retirement policy decisions that have been made by companies that terminated their DB pension plans in order to remove excess assets from overfunded pension accounts. This was a particularly interesting sample, because these companies were in the position to design and implement new policies with any economic structure.

According to Siegel's study, approximately 20 percent of companies terminating their DB plans in 1987 and 1988 replaced the terminated plans with DC plans. This is consistent with the idea of a gradual transition in plan design. Most of the other companies apparently implemented plans identical to those that had been terminated. For both the companies restoring DB plans and the companies replacing their terminated plans with DC plans, Siegel finds that retirement incentives (or their absence) were not a motivating factor in the company's decision. According to Siegel:

Not a single person mentioned retirement incentives in any aspect of the discussion. All of the firms in this sample cancelled their plans because they wanted to recoup excess assets. Almost all firms that chose defined benefit plans replaced with mirror plans. Reasons that they gave for their decision included appeasing alarmed workers, providing for long-term employees sufficiently, inertia, and their ability to save money with riskier investments. Treasurers who chose defined contribution did so because employees appreciate more knowledge and control over their assets, cash flow management is easier, and administrative costs are lessened. Again, not a single interviewee mentioned incentives for retirement as an influence on their decision.

Siegel's conclusions are much the same as those reported in this study. Even though most large companies have retirement policies that encourage retirement among older workers, these retirement incentives were not a primary motivation for the policy design.

Given the loss in productive activity caused by retirement in the United States, it is potentially worrisome that businesses do not consider the 
effects of their policies on retirement behavior more carefully. At the same time, however, there are increasing indications that companies that are dissatisfied with the retirement behavior of their workers are looking toward their retirement policies as potential instruments for changing that behavior.

The idea that pensions are deliberately designed to encourage retirement is not supported by this study. However, as the population continues to age, and as retirement policies consume an even larger percentage of corporate payrolls, businesses are likely to focus much more attention on the retirement behavior of their workers and, consequently, on the relationships between retirement policies and retirement behavior. Indeed, this same study conducted in 2020, when the baby-boom generation is retiring in record numbers, is likely to reach some very different conclusions about the key motivations for retirement policy decisions of the future.

\section{References}

Lazear, Edward. 1981. Agency, earnings profiles, productivity, and hours restrictions. American Economic Review 71 (4): 606-20.

Lumsdaine, Robin, and David Wise. 1994. Aging and labor force participation: A review of trends and explanations. In Aging in the United States and Japan, ed. Y. Noguchi and D. Wise, 7-41. Chicago: University of Chicago Press.

Siegel, Adam. 1990. The choice of pension provision: Economic theory versus managerial reality. Undergraduate thesis, Harvard University, Department of Economics. 
